\title{
MACROBRACHIUM AMAZONICUM: ACUTE TOXICITY TO NITROGEN COMPOUNDS
}

\author{
Garçon, D.P. ${ }^{1,}$, Freitas, R.S. ${ }^{1}$; Lucena, M.N..; Fabri, L.M. ${ }^{3}$; \\ Moraes, C.M. ${ }^{3}$; McNamara, J.C. ${ }^{4} \&$ Leone, F.A. $^{3}$ \\ ${ }^{1}$ Universidade Federal do Triângulo Mineiro (UFTM), Campus Iturama. \\ ${ }^{2}$ Universidade Federal do Mato Grosso do Sul (UFMS), Campus Campo Grande. \\ ${ }^{3}$ Universidade de São Paulo (USP), Filosofia Ciências e Letras de Ribeirão Preto, Departamento de Química. \\ ${ }^{4}$ Universidade de São Paulo (USP), Filosofia Ciências e Letras de Ribeirão Preto, Departamento de Biologia. \\ *Autor correspondente: danielapgarcon@yahoo.com.br
}

The Amazon River shrimp Macrobrachium amazonicum is widely distributed throughout South America, is amply exploited by artesian fisheries, and shows elevated potential for aquaculture investment: To establish the lethal critical concentration of total ammonia and nitrite after $96 \mathrm{~h}\left(\mathrm{LC}_{50}-96 \mathrm{~h}\right)$. Adult shrimps were collected from the Rio Grande River, state of Minas Gerais, Brazil, near the Água Vermelha Dam. Individual shrimps $(\mathrm{N}=10)$ were

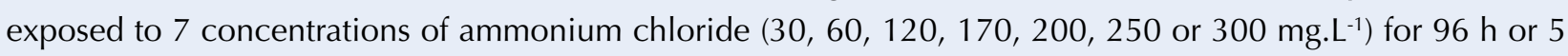

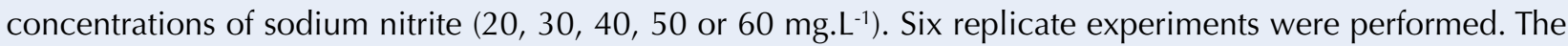
$\mathrm{LC}_{50}$ after $96 \mathrm{~h}$ exposure was calculated using a Probit analysis, and was adjusted employing a linear regression $(\mathrm{P} \leq 0.05)$. The $\mathrm{LC}_{50}$ calculated after $96 \mathrm{~h}$ exposure of $\mathrm{M}$. amazonicum was $54.27 \mathrm{mg} \cdot \mathrm{L}^{-1}$ total ammonia or 30.75 mg. $\mathrm{L}^{-1}$ nitrite. Based on these findings we recommend a safe level of $5.427 \mathrm{mg} \cdot \mathrm{L}^{-1}$ total ammonia and 3.075 $\mathrm{mg} . \mathrm{L}^{-1}$ nitrite for aquaculture production. Intraspecific genetic and physiological variation among M. amazonicum populations may explain the difference in $\mathrm{LC}_{50}-96 \mathrm{~h}$ seen between the shrimp population cultivated in the Rio Grande River and those cultivated at other facilities.

Keywords: acute toxicity; ammonia; nitrite; Macrobrachium amazonicum.

Financial support: FAPEMIG, CNPq, FAPESP, FAPEAM, INCT-ADAPTA. 